\title{
Zika Virus (ZIKV)
}

\section{German Advisory Committee Blood (Arbeitskreis Blut), Subgroup 'Assessment of Pathogens Transmissible by Blood'}

\section{Current Knowledge about the Pathogen}

Arthropod-borne viruses (arboviruses) and in particular viruses of the genus Flavivirus among the Flaviviridae have spread in many subtropical and tropical countries in recent decades [1]. These include Dengue viruses (DENV), Chikungunya virus (CHIKV), West Nile virus (WNV), and Usutu virus (USUV) [1-4]. Humans and other primates serve as virus reservoirs for DENV and CHIKV. Mosquitoes infected by the blood meal on humans serve as vector to maintain the infection cycle. International trade is regarded as vehicle for the long-distance spread of various mosquitoes.

The first outbreak of Zika virus (ZIKV) occurred on islands of the Federated States of Micronesia in 2007 [5]. Then the virus spread in the Pacific region and to the Caribbean and South and Central America [6-11].

ZIKV was first isolated in 1947 from the serum of a febrile rhesus monkey by intracerebral infection of mice [12]. The monkey served as sentinel animal for the surveillance of yellow fever virus (YFV) in the Zika forest in Uganda. About 9 months later, ZIKV was isolated in the same region from mosquitoes of the species Aedes africanus $[12,13]$. The new virus was differentiated from known viruses such as YFV or DENV by using defined antisera in neutralization tests. The isolate was named after its place of first detection in the Zika forest. In the following years, additional ZIKV were isolated from various species of mosquitoes in Africa $[14,15]$.

Few reports of sporadic cases of ZIKV disease in humans have been published prior to 2007. Individuals reported flu-like symptoms comparable to mild disease caused by DENV or CHIKV.

In general, ZIKV infection is a vector-borne disease. However, increasing numbers of vertical ZIKV infections are reported. So far, only sporadic cases of transmission through blood transfusions, sexual contact, and occupational infections have been observed [16-18].

\subsection{Characteristics of ZIKV}

Serological reactivity with other flaviviruses such as YFV, WNV, Japanese encephalitis virus (JEV), and DENV grouped ZIKV to the Spondweni serocomplex $[19,20]$. Flaviviruses have a lipid envelope derived from host cell membranes. Viral envelope glycoproteins are embedded into the lipid membrane. The viral envelope encloses the viral capsid containing the single-stranded positive-strand viral RNA genome with a size of about 11,000 nucleotides. The genome encodes a polyprotein with a size of about 3,400 amino acids, which is processed into structural and non-structural proteins by cellular and viral proteases. The genome structure corresponds to that of other flaviviruses (5'-C-prM-E-NS1 NS2A NS2B-NS3, NS4ANS4B 2K NS5-3'). The three genes for the structural proteins (capsid (C), precursor membrane protein/membrane protein (prM/M), and envelope protein (E)) are localized at the $5^{\prime}$ end of the genome, followed by the seven genes for the non-structural proteins NS1 to NS5. These proteins have either enzymatic activity (protease, RNAdependent RNA polymerase) or are involved in the regulation of viral replication $[21,22]$. The envelope protein $\mathrm{E}$ is necessary for the attachment to cells and their infection. In infected hosts, protein $\mathrm{E}$ induces neutralizing antibodies.

Phylogenetic analyses of ZIKV isolates from humans, monkeys, and mosquitoes distinguish two genotypes which are endemic in Africa or Asia [15, 23-26]. Within the African genotype, a West African and an East African genotype can de differentiated [26, 27].

Dick [13] investigated the stability of ZIKV in mouse brain suspensions. He showed that virus from carefully dried brain suspensions could be re-isolated after 30 months of storage at $0-4{ }^{\circ} \mathrm{C}$. Treatment of a brain suspension (10\%) with ether (1/1), potassium permanganate, or heat at $60^{\circ} \mathrm{C}$ for $15 \mathrm{~min}$ or at $58^{\circ} \mathrm{C}$ for $30 \mathrm{~min}$ inactivated ZIKV. Viruses in brain suspensions are rapidly inactivated by treatment with $\mathrm{pH} \leq 6.2$ or $\mathrm{pH} \geq 7.8$ [13]. Comparing these results with investigations of other flaviviruses like DENV, YFV, and WNV, ZIKV has a comparable thermal stability and sensitivity to disinfectants, alcohols, and detergents [28-30].

\subsection{Infection and Infectious Diseases}

Arbovirus-infected mosquitoes transmit virus during their blood meal on humans. Human skin biopsies were used to identify those cells in which ZIKV can multiply [31]. Similar to other flaviviruses, in the human skin fibroblasts, keratinocytes, and immature

\section{KARGER}

(c) 2016 S. Karger GmbH, Freiburg

Fax +497614520714 
dendritic cells can be infected. For infection, receptors on the cells like DC-SIGN, AXL, TYRO3, and TIM-1 are necessary $[31,32]$. Arbovirus-infected mosquitoes initiate the infection by their bite, injecting virus-containing saliva into the epidermis. The saliva can modulate the response of the cells in the epidermis, which enables the propagation of the virus in skin cells [33].

After replication in skin cells, the virus disseminates with the bloodstream. Infectious virus or viral genomes can be detected in serum and plasma in the first few days of infection.

As one of the few early reports of ZIKV-associated diseases in humans, Macnamara [34] described in 1954 the first isolation of ZIKV from the blood of a girl during the investigation of a jaundice outbreak in Nigeria. Two additional individuals showed a rise of ZIKV-specific antibodies. Isolates from humans have been described in the following years in Uganda and Nigeria [35-37]. Symptoms such as fever, headache, malaise, and fatigue were the main complaints observed [38].

Similar symptoms have been observed in a volunteer vaccinated against yellow fever after subcutaneous injection of a diluted brain suspension from a ZIKV-infected mouse [39]. After 7 days post inoculation (dpi), the individual was free from fever and other symptoms. Low titers of infectious virus were detected in the serum of the volunteer on the 4 th and 6 th dpi.

In two case reports, the courses of laboratory-acquired ZIKV infections were described. Both patients had been vaccinated against yellow fever $[16,35]$. The infection was confirmed by the isolation of ZIKV. On the first day of illness, one infected individual complained of fever, retro-orbital pain, and pain in the back, neck, and joints [16]. The second infected person had a headache and developed a maculopapular rash on the whole body and slight back and leg pains. In both cases, the symptoms disappeared within a few days. Similar symptoms have also been observed in sporadic cases of ZIKV disease in Africa and during an outbreak (involving 7 people) in Indonesia where the infection was detected by a rise of ZIKV-specific antibodies [34, 36, 37, 40].

From these and other findings observed during outbreaks, it can be deduced that the incubation period is about 2-7 days like in other flavivirus infections such as DENV or WNV [2, 3, 5, 41, 42]. It is assumed that about $80 \%$ of people who become infected with ZIKV do not develop any symptoms.

\subsubsection{First Large ZIKV Outbreak}

In 2007, the first large ZIKV epidemic was observed in Yap State, an island of the Federated States of Micronesia. Most of the diseased ZIKV-infected patients suffered from the previously described mild symptoms. However, the rapid dissemination of the pathogen and the high number of patients were unusual [5]. In the subsequent epidemic in French Polynesia in 2013, which also spread rapidly, the majority of clinically ill patients developed mild fever, body aches, maculopapular rash, and conjunctivitis [8].

\subsubsection{Guillain-Barré Syndrome}

In November 2013, it was reported that people developed a Guillain-Barré syndrome (GBS) shortly after ZIKV disease [43].
GBS is a rare but potentially fatal rapid-onset muscle weakness caused by an autoimmune reaction damaging the peripheral nervous system. Approximately two-thirds of all patients who developed GBS in this outbreak had suffered from a ZIKV infection shortly before the onset of symptoms [44]. During the ZIKV epidemic, the number of GBS cases rose by a factor of 20 compared to preceding years, with incidence rates of $1-2 / 100,000$ population $[44,45]$. It is therefore postulated that ZIKV was involved in the triggering of the acute onset of the neurological disease with inflammatory changes in the peripheral nervous system $[43,44]$.

An increase of cases with GBS was also observed in the course of the epidemic in South and Central America (Brazil, El Salvador, Colombia, Suriname, and Venezuela) in 2015/2016 [46]. Furthermore, ZIKV was isolated from the urine of 2 patients with GBS in Martinique [47]. Association of GBS with other arbovirus infections like DENV or CHIKV was reported [48, 49].

\subsubsection{Microcephaly and Other Abnormalities}

Reports of an association of ZIKV infections and microcephaly in fetuses and newborns in Brazil attracted special attention. From some regions in north-eastern Brazil, an increase of cases of microcephaly, malformation of the brain, and stillbirth were reported. In some cases, ZIKV was demonstrated in tissues, including the brain of stillbirths [50,51].

The question whether ZIKV can induce microcephaly is part of an ongoing discussion [52]. Detection of high levels of ZIKV RNA and viral particles in the brain of affected fetuses implies a causal involvement of the virus [50]. This assumption is supported by epidemiological data showing an increase of cases of microcephaly in Brazil since May 2015.

Recently, 88 pregnant women in Rio de Janeiro who reported a rash in the previous 5 days as a potential symptom of ZIKV infection were enrolled in a study [53]. A ZIKV infection was confirmed by PCR in 72 women who were between 5 and 38 weeks of gestation. Fetal ultrasonography was performed in $42 \mathrm{ZIKV}$-positive and 16 ZIKV-negative women. In 12 of 42 ZIKV-positive and none of the $16 \mathrm{ZIKV}$-negative pregnant women, fetal abnormalities including central nervous system defects were identified. At the time of the report, 2 stillbirths (36 and 38 weeks of gestation, respectively) and 6 live births of ZIKV-positive women had occurred. The 2 newborns with normal sonography were healthy; in 1 child, the prenatally diagnosed growth retardation was not confirmed, and the child is doing well. Two children showed microcephaly, and 1 child was small for gestational age but with a proportionate head circumference.

These results imply that pregnant women who are infected with ZIKV and develop symptoms of a ZIKV infection have a high risk of serious complications of pregnancy [54]. To what extent fetuses of pregnant women who undergo an asymptomatic ZIKV infection show disorders has not been sufficiently studied.

Epidemiological and virological findings, together with birth defects observed in fetuses and newborns in areas with a high incidence of ZIKV infections, support the preliminary, alarming results of the study in Rio de Janeiro [55-57]. Additionally, studies 
demonstrated that human neural progenitor cells differentiated from pluripotent cells were preferentially infected by ZIKV. This leads to dysregulation of transcription and the death of these cells $[58,59]$. This experimental system may allow studying the influence of ZIKV on the development of the fetal brain in more detail.

WHO, the Centers for Disease Control and Prevention (CDC), and other health authorities (Pan American Health Organization) have published recommendations for pregnant women living in countries which are affected by the ZIKV epidemic [60, 61]. Health authorities in some Latin American countries have also recommended postponing planned pregnancies [61]. Pregnant women who live in ZIKV-free areas are advised to avoid unnecessary travels to regions where ZIKV circulates or to protect themselves carefully against mosquito bites $[62,63]$.

In coordination with the Robert Koch-Institute, the Foreign Office and the German Society for Tropical Medicine (DTG) [64] issued similar recommendations.

\subsubsection{Routes of Transmission}

ZIKV was isolated in Africa and Asia from a variety of mosquitoes of the genus Aedes, but also from other genera [15, 26]. In principle, all mosquito species must be considered as potential vectors for ZIKV [65]. Whether and which of the various mosquito species are able to transmit ZIKV has not been systematically investigated. However, Aedes (Stegomyia) aegypti and Aedes (Stegomyia) albopictus most probably constitute the main vectors in the transmission and spread of the pathogen. These two species are part of the urban infection cycle because they take their blood meals preferentially on humans. Both mosquito species transmit also DENV and CHIKV. Both vectors have become adapted to humans and breed in the same regions where DENV, CHIKV, and ZIKV are circulating $[1,27,66]$.

Humans are the virus reservoir of ZIKV, DENV, and CHIKV in the infection cycle. Mosquitoes become infected while feeding on infected humans during the viremic phase. In the arthropods, the viruses replicate initially in the digestive tract before spreading throughout the body. The viruses also infect the salivary glands, and the pathogens are transmitted back to vertebrates with subsequent blood meals.

\subsubsection{Other Transmission Routes}

During the spread of ZIKV to the Pacific Rim and to the Americas, additional transmission routes have been identified. As early as in November 2013, blood donations were tested with a ZIKV-specific PCR in French Polynesia. About 1,500 blood donations were tested, and 42 (3\%) were positive. The donors were healthy at the time of donation, but some developed symptoms of a ZIKV infection 3-10 days later. ZIKV was isolated from PCR-positive sera, indicating that these donations were infectious [67]. The first 2 cases of transfusion-associated transmission of ZIKV were reported from Brazil [68]. The transmissions occurred in 2015. One patient was transfused after transplantation and developed fever. Post donation, the healthy donor developed symptoms of a ZIKV infection. Both recipient and donor recovered. The second patient, who later died as a result of a gunshot wound, was multi-transfused. The transmission by transfusion was verified in the first case through analysis of the ZIKV genomes of donor and recipient [69].

In French Polynesia, the first perinatal transmissions from mother to newborn have been described [70]. In 2011, it was suspected that ZIKV could be transmitted during sexual intercourse [20]. About 9 days after their return from Senegal to Colorado, USA, 2 men developed symptoms that were compatible with a flavivirus infection. In addition, hematospermia was observed in 1 of the patients. About 8 days after onset of illness, the wife of this patient also developed symptoms of a flavivirus infection, and ZIKV was confirmed. Additional cases of sexual transmissions were reported from the USA and Italy [71, 72]. Musso and co-workers [73] successfully isolated infectious ZIKV from the semen of a man with hematospermia who had developed symptoms of a ZIKV infection 2 weeks prior to the hematospermia. The semen contained about $3 \times 10^{6}$ to $1 \times 10^{8}$ genome equivalents $/ \mathrm{ml}[73,74]$. According to the presently available results, viral genomes can be detected in semen for about 10 weeks after waning of symptoms [75, 76]. So far, there are no reports about the risk of transmission through vaginal secretions. The extent to which sexual transmission of ZIKV in endemic areas or during an outbreak plays an epidemiological role is unknown.

It was demonstrated by PCR that ZIKV - like in DENV infections - was detectable in urine and saliva of patients at about the 5 th day after onset of symptoms [77-81]. Saliva samples can be of particular interest when serum is difficult to collect, especially from children and newborns.

Two days after the appearance of disease symptoms, ZIKV is excreted in urine and can be detected by PCR for 15-20 days [81, 82]. The question arises whether ZIKV can also be transmitted by these body fluids $[81,83]$. So far, there are no reports on suspected transmission of ZIKV by virus-containing saliva or urine.

\subsection{Epidemiology}

The epidemiology of DENV, CHIKV, and ZIKV infections seems to be closely linked to distribution areas of $A$. aegypti and $A$. albopictus [66, 84]. During the last decades, both Aedes species have spread from their original distribution areas in Asia (A. albopictus, tiger mosquito) and Africa (A. aegypti, yellow fever mosquito) to the Americas and Europe. The spread of mosquitoes is facilitated by international transport of goods, mobility, and airline travel.

The simultaneous circulation of DENV and CHIKV in areas where ZIKV outbreaks are occurring is a challenge for the health care systems because these virus infections exhibit similar symptoms [85]. Usually, testing for ZIKV was only performed after ruling out an infection with DENV or CHIKV. Serologic differential diagnosis of flaviviruses is complicated by the frequently observed cross-reactions in antibody screening tests like ELISA and hemagglutination inhibition tests.

Dick [13] described the detection of ZIKV-specific antibodies in humans for the first time in 1952. During the following years, sero- 
logical studies indicated that ZIKV infections were widespread in African countries such as Uganda, Egypt, Senegal, and Nigeria as well as in Asian countries such as Pakistan, Thailand, Indonesia, and the Philippines, but only few infected individuals developed symptoms [37, 86-89]. It was therefore assumed that ZIKV infections usually are asymptomatic or that only very mild symptoms are induced.

Until the outbreak on Yap in 2007, most virus isolates derived from various mosquito species, and about $10 \mathrm{ZIKV}$ were isolated from humans $[15,26]$. Human isolates were obtained in the context of studies for the dissemination and monitoring of other arboviruses, especially YFV [34, 36, 37].

The partly high seroprevalence in different regions of Africa and Asia has led to the assumption that there are two different cycles of infection, a sylvatic and an urban cycle. Evidence of ZIKVspecific antibodies in monkeys in Africa and Asia and the isolation of ZIKV from monkeys corroborate the existence of a sylvatic cycle $[13,15,90,91]$.

Humans are the virus reservoir in the urban cycle. Whether animals can also serve as reservoirs in this cycle is not known. In some cases, antibodies directed against ZIKV were demonstrated in various animal species such as rodents and livestock [88]. It has already been shown that mice can be experimentally infected with ZIKV by intracerebral or intraperitoneal inoculation or by mosquito bites $[12,15,37,92]$. It is unknown whether these experiments prove that rodents are a potential reservoir for ZIKV or represent a deadend host.

In the urban infection cycle, $A$. albopictus and $A$. aegypti have a high vector competence for transmission of DENV and CHIKV and also for ZIKV. Both mosquito species breed mainly in urban areas. Their vector competence is demonstrated by experimental oral infection of mosquitoes with ZIKV [92, 93].

In April 2007, several cases of dengue-like infection were observed on Yap [5, 94]. It was unexpected that ZIKV caused this outbreak with symptomatic cases. In a survey on Yap, randomly selected household residents were tested for markers of a ZIKV infection. In this investigation, 49 confirmed and 59 probable ZIKV cases were identified. Serosurveillance of household residents allowed for an estimation of the ZIKV epidemic (people 3 years or older). About 5,000 of a total of 6,800 inhabitants of the island (73\%) were infected with ZIKV between April and July 2007 [5]. $80 \%$ of all infections were asymptomatic. Phylogenetic analyses of isolates from patients showed that the isolates belonged to the Asian genotype showing a close relationship to a Cambodian isolate $[15,24]$. Entomological investigations on Yap suggested that Aedes henselli most likely served as vector.

In October 2013, symptomatic ZIKV infections were observed in French Polynesia $[8,44,45,95]$. Based on the data collected in French Polynesia in the years 2013 and 2014, it has been estimated that in the total population of about 270,000 between 28,000 and 32,000 people developed a ZIKV disease. The rapid spread of ZIKV in French Polynesia within a very short time is supported by the analysis of blood donations in the years 2011-2013 for antibodies against DENV, ZIKV, JEV, and WNV. In these 2 years, about $80 \%$ of donations were positive for DENV, but only less than $1 \%$ responded with ZIKV antigens and about 3\% with CHIKV [96]. The extent to which the reactivity with ZIKV was due to antibodies directed against this virus or whether cross-reactions in the test systems were responsible for the reactivity was not investigated further.

In 2014, autochthonous infections with ZIKV were diagnosed on Oceanian islands such as New Caledonia and the Cook Islands [67]. Also in 2014, ZIKV infections were observed on Easter Island (Chile), the first detection of the pathogen in the Americas. The first autochthonous infections in Brazil were described at the beginning of 2015 [97].

DENV is endemic in Brazil [98]. The first cases of CHIKV were diagnosed in September 2014 in north-eastern Brazil. It is assumed that CHIKV has been imported to Brazil via the Caribbean [99]. The co-circulation of these two arboviruses, which induce comparable symptoms and are transmitted by the same vectors, caused difficulties in diagnostics. At the beginning of 2015, patients with a dengue-like syndrome were reported in Natal, a city in the northeast of Brazil. From February to the end of April 2015, approximately 7,000 cases were reported from north-eastern states of Brazil. Differential diagnostics excluded infections with DENV or CHIKV. At the end of April 2015, it was notified that the disease was caused by ZIKV of the Asian genotype closely related to isolates from French Polynesia [25].

At the end of March 2016, ZIKV had spread in South and Central America. Furthermore, since the end of 2015, a ZIKV outbreak with more than 7,000 infected people was observed in Cape Verde. So far, there is no information available whether this outbreak was caused by the Asian or the African genotype. Up to now, autochthonous infections were reported in 42 countries worldwide [100, 101].

In Europe, ZIKV infections were diagnosed in travellers returning from ZIKV-endemic areas (including Thailand, Maldives, Caribbean, Brazil, Central America, Borneo) [102-106]. In Slovenia, a ZIKV infection was suspected in a pregnant woman who had acquired a ZIKV infection in Brazil in the first trimester of gestation [50]. Ultrasonography in the 29th and 32nd week of pregnancy showed growth anomalies of the fetus. Termination of the pregnancy was performed at the 32nd week of gestation. Pathological findings confirmed microcephaly. ZIKV could only be detected in the fetal brain. Phylogenetic analysis of the whole genome confirmed the close relationship of this virus with a sequence from French Polynesia, which is in line with the finding that Brazilian isolates are closely related to the Asian genotype.

\subsubsection{Detection of ZIKV in Mosquitoes}

The first isolation of ZIKV from the mosquito A. africanus was achieved about the same time when ZIKV was isolated from a rhesus monkey in the Zika forest in Uganda $[12,13]$. In the following decades, ZIKV was isolated from various mosquitoes of the genus Aedes in African and Asian countries, but isolates obtained from other genera were also described [15, 26, 27, 107, 108].

As early as in the 1950s, it was investigated whether female $A$. aegypti mosquitoes orally infected with ZIKV were able to transmit 
ZIKV to laboratory animals [92]. It can be postulated that the kinetics of ZIKV replication in mosquitoes is dependent on time and temperature. It was shown that a rise of infectious ZIKV could be detected in salivary glands of orally infected $A$. aegypti which were kept at a temperature of $29^{\circ} \mathrm{C}$ for 10 days.

Transmission of virus is only possible if the viral titer in the salivary glands of mosquitoes is high enough to infect a susceptible host during the next blood meal $[3,109]$. Whether and in which regions of Germany the necessary average temperatures for the development of vector competence of mosquitoes can be reached and which endemic mosquito species might serve as vectors to transmit ZIKV has not yet been studied.

In Senegal, ZIKV was isolated from a pool of male Aedes furcifer [108]. This is an indication that ZIKV can be transmitted transovarially to male and female offspring [109]. The extent to which this route of transmission is of epidemiological significance for the maintenance of the spread of ZIKV is not known. The importance of vertical transmission of other arboviruses such as DENV is controversial [110]. Epidemiological and entomological studies suggest that during the outbreaks on Yap A. henselli and in French Polynesia A. aegypti and Aedes polynesiensis could have served as vectors [5, 8, $111,112]$. Based on studies on the spread of DENV and CHIKV infections in Brazil and other Latin American countries, it is postulated that mainly A. aegypti and A. albopictus serve as vectors for ZIKV, DENV, and CHIKV $[11,17]$. In urban areas, A. aegypti and A. albopictus prefer breeding in the vicinity of humans and lay their eggs in ponds, flowerpots, empty cans, grave vessels, and other water-filled containers. Female $A$. aegypti mosquitoes prefer to bite people during the day both in homes and in the environment. A. albopictus have a broad host spectrum and take the blood meal preferably on humans, but also on other vertebrates such as cats, dogs, and other mammals. This mosquito species usually bites outside of buildings. Both A. aegypti and A. albopictus are considered as potential vectors for ZIKV; however, differences in the vectorial competence to transmit arboviruses like DENV and CHIKV have been described [113]. Therefore, it can be assumed that under appropriate climatic conditions autochthonous transmissions of ZIKV can be expected in the distribution area of the Aedes mosquitoes and probably of other mosquito species in Europe as well [114-116]. Potential sources of infection for mosquitoes in Germany are primarily travellers returning from ZIKV-endemic areas.

In recent years, several research projects have been initiated in Germany and in Europe concerning the regional distribution of domestic mosquito species and changes in their distribution over time $[115,117]$. Another objective of the projects is the identification of exotic mosquito species such as A. albopictus and A. aegypti which are imported mainly by the international transport of goods. In addition, the question is addressed whether or not domestic or exotic mosquitoes have the competence to propagate relevant pathogens such as ZIKV and transmit them to humans. It is known that same mosquito species occurring in different regions may have variable vector competence for a particular virus [118].

Over the past decade, indigenous DENV and CHIKV infections were repeatedly observed in southern Europe $[119,120]$. It is re- markable that there is an apparent coincidence of the occurrence of these diseases and the distribution of A. albopictus in Europe [118]. In Germany, the presence of A. albopictus and other exotic mosquitoes and breeding sites were found close to international transport routes $[115,117,121]$. With these findings in mind, it was discussed whether A. albopictus might become established in Germany in regions with mild climate like the Upper Rhine [122]. The repeated and probably continuous importation of exotic mosquito species into Germany and other European regions requires coordinated surveillance in Europe and the development of control strategies to counteract efficiently and as early as possible the importation and spread of serious arbovirus-induced illnesses [117].

\subsection{Detection Methods and Their Significance}

Due to the lack of specific clinical symptoms, a ZIKV infection can only be diagnosed by determining ZIKV-specific antibodies, isolation of virus in newborn mice, mosquitoes, or cell cultures, or by the detection of ZIKV genome by NAT.

\subsubsection{Serological Methods for ZIKV}

The serological diagnosis for the detection of ZIKV-specific antibodies can be hampered by pronounced cross-reactivity of antibodies induced by infections with or vaccination against flaviviruses like YFV, JEV, tick-borne encephalitis virus (TBEV), and DENV. For a long time, complement fixation and hemagglutination inhibition tests were used in endemic regions for the detection of YFV, DENV, and ZIKV [86, 123, 124]. The confirmation and differentiation of reactive sera was performed with neutralization tests in mice [125].

Recently, commercial tests for the detection of antibodies directed against ZIKV became available. A ZIKV IgM capture assay received temporary approval from the Food and Drug Administration (FDA) as in vitro test for the detection of human antibodies in serum and cerebrospinal fluid [126].

Further commercial tests for the detection of IgM and IgG directed against ZIKV are available (immunofluorescence assay with ZIKV-infected cells or ELISA based on genetically engineered ZIKV antigen).

Virus-specific IgM antibodies are detectable about 2-4 days after the onset of symptoms. These antibodies persist for about 2-12 weeks. The cross-reactivity of antibodies to other flaviviruses must be considered when interpreting the results [94, 102, 125, $127,128]$. Reactive test results should be confirmed by neutralization tests using ZIKV (e.g. plaque reduction neutralization test; PRNT). Since cross-reactions between flaviviruses were observed also in PRNT, sera should be tested in parallel with other flaviviruses. In addition to the antibody detection systems for differential diagnostics, a DENV antigen capture assay on the basis of the NS1 protein can be applied [129]. The CDC have developed an algorithm for the serological diagnostics of the arboviruses DENV, $\mathrm{CHIKV}$, and ZIKV which considers the cross-reactivity of IgM antibodies within the genus flavivirus [125]. 


\subsubsection{Detection of the Virus Genome}

The viremic phase during a ZIKV infection is short, and genomes can usually only be detected up to 8 days (usually 5 days) after appearance of symptoms. The highest virus load is measured on the first day of the disease. This implies that the patient is already viremic during the incubation period of 2-7 days prior to onset of symptoms [66]. ZIKV genome can be detected in saliva and urine up to 20-30 days after onset of symptoms, which is longer than its detection in blood $[66,81,83]$.

Of particular interest is the detection of ZIKV in semen because infectious virus can be excreted for a longer time with semen, and virus was detected up to 62 days after onset of symptoms [74, 130]. It is unknown whether virus is excreted during an asymptomatic ZIKV infection. For further characterization and differentiation of NAT-positive samples, genome sequencing followed by phylogenetic analysis enables molecular epidemiological classification of the isolates by using PCR $[15,131,132]$.

\subsubsection{Virus Isolation}

For the detection and propagation of ZIKV, monkey cells (Vero) or mosquito cells like AP61 (Aedes pseudoscutellaris) or C6/36 monolayer (A. albopictus) and intrathoracic inoculation of mosquitoes (Toxorhynchites splendens) are used [23,67].

\section{Blood and Plasma Donors}

\subsection{Prevalence and Incidence in Donor Populations}

ZIKV is an imported disease in Germany. All known 25-30 cases had acquired the infection in ZIKV-endemic areas [102, 133, 134]. It is unknown how many asymptomatic cases occurred in returning travellers. As there is no testing of people at risk for a ZIK infection or donations for ZIKV-specific antibodies or other viral markers, there is no information on the precise prevalence in the donor population.

\subsection{Definition of Exclusion Criteria}

According to the hemotherapy guidelines [135], blood donors have to be generally deferred from donating in the case of a particular epidemiological situation. For ZIKV, this epidemiological situation was defined by the decision of the Paul Ehrlich Institute (published March 3, 2016). In whole blood, cellular blood components, and fresh frozen plasma, which are not subjected to procedures for effective virus inactivation, no starting material should be used from donors who have returned from a ZIKV-endemic region in the last 4 weeks prior to donation. In various studies, it was shown that ZIKV genomes could be detected by RT-PCR in serum or plasma up to 11 days after onset of symptoms, but usually only up to 5 days [96]. A deferral for 4 weeks was therefore defined.
In view of the findings that ZIKV can be excreted in semen up to 62 days after onset of symptoms, the FDA - unlike the competent authority in Germany - published recommendations that sexual partners of persons who suffered from a ZIKV infection or returned from a ZIKV-endemic region in the last 3 months should self-defer from donation for 4 weeks after the last sexual contact [136].

\subsection{Donor Testing and Significance}

Testing of donations is not performed in Germany because ZIKV is not endemic and donor deferral strategies for returning travellers are considered to be effective.

\subsection{Donor Interviews}

Donors should be interviewed regarding stays in ZIKV-endemic areas or in regions where outbreaks are currently observed. Current information on ZIKV-endemic areas can be accessed on the web page of the WHO or the European Centre for Disease Prevention and Control (ECDC) [100, 101].

\subsection{Donor Information and Counselling}

Specific advice on ZIKV infections and prophylaxis can be given by specialized physicians.

\section{Recipients}

\subsection{Prevalence and Incidence of Blood-Associated Infections and Infectious Diseases in Recipient Populations}

Only very few transfusion-transmitted ZIKV infections have been reported in endemic regions. There are no data with respect to prevalence and incidence of blood-borne ZIKV infections.

\subsection{Immune Status (Resistance, Existing Immunity, Immune Re- sponse, Age, Exogenous Factors)}

Infection with ZIKV is usually resolved within $2-3$ weeks. A natural resistance to ZIKV is unknown. So far, only imported cases have been diagnosed in Germany; therefore, there is no immunity in the population.

An age-dependent course of an infection associated with more severe symptoms has not been described. In an HIV-infected individual, the infection had a mild course. A specific antiviral therapy is not available. No additional risk factors for complications could be identified so far. 


\subsection{Severity and Course of the Disease}

Usually ZIKV infections transmitted by mosquitoes are benign and self-limiting. In endemic regions, neurological disorders such as GBS have been described and linked to vector-borne ZIKV infections [45]. Especially in Brazil, an increase of malformations in fetuses and newborns like microcephaly and other neurological abnormalities have been described and associated with the ZIKV epidemic $[42,52,62,137]$. Epidemiological, virological and pathological findings show an association of malformations in fetuses and neonates with infections of the pregnant women in the 1st and 2nd trimester of gestation $[50,138]$. The few recipients of infectious blood products experienced only mild symptoms. Whether there are differences in the course of transfusion-associated infections and of those transmitted by vectors cannot be assessed due to the small number of transfusion-associated infections.

\subsection{Therapy and Prophylaxis}

There is only symptomatic therapy available for the treatment of ZIKV-associated diseases [139]. As no vaccine is available yet, the primary prevention of a ZIKV infection is the prevention of mosquito bites. Since A. aegypti and A. albopictus are preferably diurnal and reside both outside and inside buildings, light longsleeved outerwear and pants should be worn and repellents used the whole day. Methods for eradication or control of the mosquito populations are presently under development and their applicability is investigated $[6,140]$.

Donor selection criteria should defer individuals from endemic regions for appropriate periods of time. In endemic regions, NAT testing of donations could be considered if a suitable test is available.

\subsection{Transmissibility}

Usually, ZIKV is transmitted by the bite of an infected mosquito during a blood meal. Recently, further transmission routes have been reported: infection of partners during unprotected intercourse by infectious semen and perinatal and intrauterine transmissions $[42,62,141]$. Whether ZIKV is transmitted by breast milk from the mother to a newborn should be further examined [142].

The high number of virus-positive blood donations during the ZIKV epidemic in French Polynesia was an additional indication of the possible ZIKV transmission by transfusion [67]. In Brazil, the first transmissions of ZIKV through blood transfusions were observed in 2015 [68, 143].

\subsection{Frequency of Administration, Type and Amount of Blood Products}

Transmission of ZIKV can occur by non-inactivated blood components such as red blood cell and platelet concentrates or fresh frozen plasma. Viral inactivation procedures have been developed for plasma and platelet preparations. For red blood cell concentrates, no effective inactivation methods are available yet. Plasma derivatives are subjected to procedures that contain several specific manufacturing steps for the inactivation/removal of viruses (see 4.2).

\section{Blood Products}

\subsection{Infectious Load of the Starting Material and Test Methods}

The virus load of donated blood or plasma can be determined by the detection of viral genomes. Investigations of PCR-positive blood donations in French Polynesia reported a load of 103-107 genome copies $/ \mathrm{ml}$ serum [96]. The donors were healthy at the time of the donation. Some of the donors developed symptoms of a ZIKV infection 3-10 days post donation [67]. As yet, no information on the virus load of plasma pools for the production of plasma products is available. Because of the relatively short viremic phase and the epidemiological situation in those countries in which plasma for fractionation is collected, high ZIKV loads are not expected in plasma pools from non-endemic regions.

\subsection{Methods for Removal and Inactivation of the Infectious Agent}

Inactivation and elimination methods which are used in the preparation of blood and plasma products are validated with model viruses as well as with relevant viruses. The flaviviruses used in the individual process steps (bovine viral diarrhea virus, TBEV, DENV, and WNV) have a comparable sensitivity to solvents and detergents (SD method), low $\mathrm{pH}$, or heat treatment $[28,30$, 144-147].

In the production of plasma derivatives, the combination of process steps has proved to be highly efficient in inactivating or eliminating flaviviruses. Therefore, plasma derivatives are safe. The SD method used for the production of plasma inactivates flaviviruses and other enveloped viruses safely and quickly [148]. Therefore, it is effective for the inactivation of ZIKV.

Pathogen inactivation procedures developed for platelet concentrates can inactivate viruses including flaviviruses and other pathogens [149-151].

\subsection{Feasibility and Validation of Procedures for Removal/Inacti- vation of the Infectious Agents}

ZIKV can be propagated in cell culture to high titers [96]. Individual blood components or intermediates of the production process of plasma derivatives can be experimentally contaminated with ZIKV. The efficacy of methods for the inactivation/elimination of ZIKV in the individual production steps can be followed by 
the determination of infectious virus using a plaque assay (plaqueforming units) or by end-point titration (tissue culture infectious dose $50 \%)$.

\section{Discussion}

In general, the course of a ZIKV infection is asymptomatic and self-limiting. Reports on the ZIKV epidemic in French Polynesia (2013) have already pointed to the risk of transmission of ZIKV by blood. In Brazil, the first 2 transfusion-associated transmissions of ZIKV were reported; in both cases, the donors showed no symptoms of an infection at the time of donation. Sequence analysis of the ZIKV genomes isolated from the donation and the recipient confirmed the transmission by transfusion in one case.

Blood components, SD plasma, and plasma derivatives, such as immunoglobulin and clotting factor concentrate which are prepared with validated, effective methods of virus inactivation, can be considered ZIKV safe.

The risk of transfusion-associated virus transmission by noninactivated blood components cannot be completely ruled out in Germany. The low number of reports of transmission through blood components in endemic areas could be due to the fact that many infections are asymptomatic or only mild symptoms are observed and are therefore not detected.

Testing of donations for viral genome by NAT would reduce the risk of transmission by non-inactivated blood components and might be an option in endemic areas. We believe that the introduction of a ZIKV-PCR screening of blood donations in Germany is currently not necessary because of the epidemiological situation. It is expected that the recent introduction of mandatory reporting of arbovirus infections in Germany will provide a better overview of imported arbovirus infections including ZIKV infections and will enable the recognition of autochthonous virus transmissions [152].

Deferral of potential donors returning from areas where ZIKV circulates for 4 weeks is reasonable in view of the documented incubation and viremia periods. The length of the deferral period should be re-evaluated if new data on the course of the infection becomes available. Although sexual transmission has been documented, we believe that a general donor deferral of sexual partners of returning individuals from ZIKV-endemic regions does not seem indicated in Germany due to the very low numbers of imported infections and the short incubation period. This decision might be subject to re-evaluation depending on the further spread of ZIKV.

According to current knowledge, different mosquito species, particularly A. aegypti and A. albopictus, play an essential role as vectors in the spread of ZIKV. To what extent domestic mosquitoes can be infected with ZIKV and may play a role as vectors needs to be investigated. The capacity to serve as a vector depends mainly on the local climatic conditions. Knowledge of the temporal and geographical distribution of mosquito species occurring in Germany and their vector competence for the transmission of serious (exotic) diseases would allow a better evaluation of the general risk of arbovirus infections, including the specific risk of the spread of ZIKV.

This paper was completed on March 16, 2016 and approved by the German Advisory Committee Blood (Arbeitskreis Blut) on April 13, 2016. It was compiled by the members of the subgroup 'Assessment of Pathogens Transmissible by Blood' of the German Advisory Committee Blood (Arbeitskreis Blut):

Prof. Dr. Georg Pauli

Prof. Dr. Martin Aepfelbacher

Dr. Ursula Bauerfeind

PD Dr. Isabelle Bekeredjian-Ding

PD Dr. Johannes Blümel

Prof. Dr. Reinhard Burger

Prof. Dr. Markus Funk

Dr. Albrecht Gröner

Prof. Dr. Lutz Gürtler

Dr. Margarethe Heiden

Prof. Dr. Martin Hildebrandt

Prof. Dr. Dr. Bernd Jansen

Dr. Ruth Offergeld

Dr. Uwe Schlenkrich

Dr. Volkmar Schottstedt

Prof. Dr. Rainer Seitz

PD Dr. Dorothea Stahl

Dr. Johanna Strobel

Dr. Hannelore Willkommen.

\section{References}

1 Kilpatrick AM, Randolph SE: Drivers, dynamics, and control of emerging vector-borne zoonotic diseases. Lancet 2012;380:1946-1955.

2 Gürtler L, Bauerfeind U, Blümel J, Burger R, Drosten C, Gröner A, Heiden M, Hildebrandt M, Jansen B, Montag-Lessing T, Offergeld R, Pauli G, Seitz R, Schlenkrich U, Schottstedt V, Strobel J, Willkommen $\mathrm{H}$ : Dengue fever virus (DENV). Transfus Med Hemother 2011;38:318-330.

3 Pauli G, Bauerfeind U, Blümel J, Burger R, Drosten C, Gröner A, Gürtler L, Heiden M, Hildebrandt $M$, Jansen B, Montag-Lessing T, Offergeld R, Seitz R, Schlenkrich U, Schottstedt V, Strobel J, Willkommen H: West Nile virus. Transfus Med Hemother 2013;40: 265-284.
4 Pauli G, Bauerfeind U, Blümel J, Burger R, Drosten C, Gröner A, Gürtler L, Heiden M, Hildebrandt $M$, Jansen B, Offergeld R, Seitz R, Schlenkrich U, Schottstedt V, Strobel J, Willkommen H: Usutu virus. Transfus Med Hemother 2014;41:73-82.

5 Duffy MR, Chen TH, Hancock WT, Powers AM, Kool JL, Lanciotti RS, Pretrick M, Marfel M, Holzbauer S, Dubray C, Guillaumot L, Griggs A, Bel M, Lambert AJ, Laven J, Kosoy O, Panella A, Biggerstaff BJ, Fischer M, Hayes EB: Zika virus outbreak on Yap Island, Federated States of Micronesia. N Engl J Med 2009;360: 2536-2543.

6 Ioos S, Mallet HP, Leparc Goffart I, Gauthier V, Cardoso T, Herida M: Current Zika virus epidemiology and recent epidemics. Med Mal Infect 2014;44:302307.
7 Hayes EB: Zika virus outside Africa. Emerg Infect Dis 2009;15:1347-1350.

8 Cao-Lormeau VM, Roche C, Teissier A, Robin E, Berry AL, Mallet HP, Sall AA, Musso D: Zika virus, French Polynesia, South Pacific, 2013. Emerg Infect Dis 2014;20:1085-1086.

9 Zanluca C, Melo VCA, Mosimann ALP, Santos GIV, Santos CND, Luz K: First report of autochthonous transmission of Zika virus in Brazil. Mem Inst Oswaldo Cruz 2015;110:569-572.

10 Musso D: Zika virus transmission from French Polynesia to Brazil. Emerg Infect Dis 2015;21:1887.

11 Hennessey M, Fischer M, Staples JE: Zika virus spreads to new areas - region of the Americas, May 2015-January 2016. MMWR Morb Mortal Wkly Rep 2016;65: $55-58$. 
12 Dick GW, Kitchen SF, Haddow AJ: Zika virus. I. Isolations and serological specificity. Trans R Soc Trop Med Hyg 1952;46:509-520.

13 Dick GW: Zika virus. II. Pathogenicity and physical properties. Trans R Soc Trop Med Hyg 1952;46:521534.

14 Haddow AJ, Williams MC, Woodall JP, Simpson DI, Goma LK: Twelve isolations of Zika virus from Aedes (Stegomyia) africanus (Theobald) taken in and above a Uganda forest. Bull World Health Organ 1964;31:57-69.

15 Haddow AD, Schuh AJ, Yasuda CY, Kasper MR, Heang V, Huy R, Guzman H, Tesh RB, Weaver SC: Genetic characterization of Zika virus strains: geographic expansion of the Asian lineage. PLoS Negl Trop Dis 2012;6:e1477.

16 Filipe AR, Martins CM, Rocha H: Laboratory infection with Zika virus after vaccination against yellow fever. Arch Gesamte Virusforsch 1973;43:315-319.

17 Marcondes CB, Ximenes MF: Zika virus in Brazil and the danger of infestation by Aedes (Stegomyia) mosquitoes. Rev Soc Bras Med Trop 2016;49:4-10.

18 Higgs S: Zika virus: emergence and emergency. Vector Borne Zoonotic Dis 2016;16:75-76.

19 Mansfield KL, Horton DL, Johnson N, Li L, Barrett AD, Smith DJ, Galbraith SE, Solomon T, Fooks AR Flavivirus-induced antibody cross-reactivity. J Gen Virol 2011;92:2821-2829.

20 Foy BD, Kobylinski KC, Foy JLC, Blitvich BJ, Travassos da Rosa A, Haddow AD, Lanciotti RS, Tesh RB: Probable non-vector-borne transmission of Zika virus, Colorado, USA. Emerg Infect Dis 2011;17:880-882.

21 Blázquez AB, Escribano-Romero E, Merino-Ramos T, Saiz JC, Martín-Acebes MA: Stress responses in flavivirus-infected cells: activation of unfolded protein response and autophagy. Front Microbiol 2014;5:266.

22 Klema VJ, Padmanabhan R, Choi KH: Flaviviral replication complex: coordination between RNA synthesis and 5 '-RNA capping. Viruses 2015;7:4640-4656.

23 Alera MT, Hermann L, Tac-An IA, Klungthong C, Rutvisuttinunt W, Manasatienkij W, Villa D, Thaisomboonsuk B, Velasco JM, Chinnawirotpisan P, Lago CB, Roque VG Jr, Macareo LR, Srikiatkhachorn A, Fernandez S, Yoon IK: Zika virus infection, Philippines, 2012. Emerg Infect Dis 2015;21:722-724.

24 Heang V, Yasuda CY, Sovann L, Haddow AD, Travassos da Rosa AP, Tesh RB, Kasper MR: Zika virus infection, Cambodia, 2010. Emerg Infect Dis 2012;18:349-351.

25 Campos GS, Bandeira AC, Sardi SI: Zika virus outbreak, Bahia, Brazil. Emerg Infect Dis 2015;21:18851886

26 Faye O, Freire CC, Iamarino A, Faye O, de Oliveira JV, Diallo M, Zanotto PM, Sall AA: Molecular evolution of Zika virus during its emergence in the 20th century. PLoS Negl Trop Dis 2014;8:e2636.

27 Grard G, Caron M, Mombo IM, Nkoghe D, Mbou Ondo S, Jiolle D, Fontenille D, Paupy C, Leroy EM: Zika virus in Gabon (Central Africa) - 2007: a new threat from Aedes albopictus? PLoS Negl Trop Dis 2014;8:e2681.

28 Kreil TR, Berting A, Kistner O, Kindermann J: West Nile virus and the safety of plasma derivatives: verification of high safety margins, and the validity of predictions based on model virus data. Transfusion 2003;43: 1023-1028.

29 Fang Y, Brault AC, Reisen WK: Comparative thermostability of West Nile, St. Louis encephalitis, and western equine encephalomyelitis viruses during heat inactivation for serologic diagnostics. Am J Trop Med Hyg 2009;80:862-863.

30 Remington KM, Trejo SR, Buczynski G, Li H, Osheroff WP, Brown JP, Renfrow H, Reynolds R, Pifat DY: Inactivation of West Nile virus, vaccinia virus and viral surrogates for relevant and emergent viral pathogens in plasma-derived products. Vox Sang 2004;87:10-18.
31 Hamel R, Dejarnac O, Wichit S, Ekchariyawat P, Neyret A, Luplertlop N, Perera-Lecoin M, Surasombatpattana P, Talignani L, Thomas F, Cao-Lormeau V-M, Choumet V, Briant L, Desprès P, Amara A, Yssel $\mathrm{H}$, Missé D: Biology of Zika virus infection in human skin cells. J Virol 2015;89:8880-8896.

32 Perera-Lecoin M, Meertens L, Carnec X, Amara A: Flavivirus entry receptors: an update. Viruses 2014;6: 69-88.

33 Briant L, Desprès $P$, Choumet V, Missé D: Role of skin immune cells on the host susceptibility to mosquitoborne viruses. Virology 2014;464-465:26-32.

34 Macnamara FN: Zika virus: a report on three cases of human infection during an epidemic of jaundice in $\mathrm{Ni}$ geria. Trans R Soc Trop Med Hyg 1954;48:139-145.

35 Simpson DI: Zika virus infection in man. Trans R Soc Trop Med Hyg 1964;58:335-338.

36 Moore DL, Causey OR, Carey DE, Reddy S, Cooke AR, Akinkugbe FM, David-West TS, Kemp GE: Arthropod-borne viral infection of man in Nigeria, 19641970. Ann Trop Med Parasitol 1975;69:49-64.

37 Fagbami AH: Zika virus infections in Nigeria: virologi$\mathrm{cal}$ and seroepidemiological investigations in Oyo State. J Hyg (Lond) 1979;83:213-219.

38 Keighley CL, Saunderson RB, Kok J, Dwyer DE: Viral exanthems. Curr Opin Infect Dis 2015;28:139-150.

39 Bearcroft WG: Zika virus infection experimentally induced in a human volunteer. Trans R Soc Trop Med Hyg 1956;50:442-448.

40 Olson JG, Ksiazek TG, Suhandiman, Triwibowo: Zika virus, a cause of fever in Central Java, Indonesia. Trans R Soc Trop Med Hyg 1981;75:389-393.

41 Rudolph KE, Lessler J, Moloney RM, Kmush B, Cummings DAT: Incubation periods of mosquito-borne viral infections: a systematic review. Am J Trop Med Hyg 2014;90:882-891.

42 Chan JF, Choi GK, Yip CC, Cheng VC, Yuen KY: Zika fever and congenital Zika syndrome: an unexpected emerging arboviral disease. J Infect 2016;72:507-524.

43 Oehler E, Watrin L, Larre P, Leparc-Goffart I, Lastère S, Valour F, Baudouin L, Mallet H, Musso D, Ghawche F: Zika virus infection complicated by Guillain-Barré syndrome - case report, French Polynesia, December 2013. Euro Surveill 2014;19:pii=20720.

44 Mallet HP, Vial AL, Musso D: BISES: Bulletin d'information sanitaires, épidémiologiques et statistiques. Bilan de l'épidemié à virus zika en Polynésie française, 2013-2014. Papeete: Bureau de veille sanitaire (BVS) Polynésie française; 2015 www.hygienepublique.gov.pf/IMG/pdf/no13_-_mai_2015__zika.pdf (last accessed September 27, 2016)

45 Cao-Lormeau VM, Blake A, Mons S, Lastère S, Roche C, Vanhomwegen J, Dub T, Baudouin L, Teissier A, Larre P, Vial AL, Decam C, Choumet V, Halstead SK, Willison HJ, Musset L, Manuguerra JC, Despres P, Fournier E, Mallet HP, Musso D, Fontanet A, Neil J, Ghawché F: Guillain-Barré syndrome outbreak associated with Zika virus infection in French Polynesia: a case-control study. Lancet 2016;387:1531-1539.

46 WHO: World Health Organization. Zika Virus, Microcephaly and Guillain-Barré Syndrome - Situation Report 31 March 2016. Accessed 8 April 2016. who.int/ emergencies/zika-virus/situation-report/31march-2016/en/ (last accessed September 27, 2016).

47 Rozé B, Najioullah F, Fergé JL, Apetse K, Brouste Y, Cesaire R, Fagour C, Fagour L, Hochedez P, Jeannin S, Joux J, Mehdaoui H, Valentino R, Signate A, Cabié A; GBS Zika Working Group: Zika virus detection in urine from patients with Guillain-Barré syndrome on Martinique, January 2016. Euro Surveill 2016;21:pii= 30154

48 Ralapanawa DM, Kularatne SA, Jayalath WA: Guillain-Barre syndrome following dengue fever and literature review. BMC Res Notes 2015;8:729.
49 Oehler E, Fournier E, Leparc-Goffart I, Larre P, Cubizolle S, Sookhareea C, Lastère S, Ghawche F: Increase in cases of Guillain-Barré syndrome during a Chikungunya outbreak, French Polynesia, 2014 to 2015. Euro Surveill 2015;20:pii=30079.

50 Mlakar J, Korva M, Tul N, Popović M, Poljšak-Prijatelj M, Mraz J, Kolenc M, Resman Rus K, Vesnaver Vipotnik T, Fabjan Vodušek V, Vizjak A, Pižem J, Petrovec M, Avšič Županc T: Zika virus associated with microcephaly. N Engl J Med 2016;374:951-958.

51 Schuler-Faccini L, Ribeiro EM, Feitosa IM, Horovitz DD, Cavalcanti DP, Pessoa A, Doriqui MJ, Neri JI, Neto JM, Wanderley HY, Cernach M, El-Husny AS, Pone MV, Serao CL, Sanseverino MT; Brazilian Medical Genetics Society - Zika Embryopathy Task Force: Possible association between Zika virus infection and microcephaly - Brazil, 2015. MMWR Morb Mortal Wkly Rep 2016;65:59-62.

52 Frank C, Faber M, Stark K: Causal or not: applying the Bradford Hill aspects of evidence to the association between Zika virus and microcephaly. EMBO Mol Med 2016;8:305-307.

53 Brasil P, Pereira JP Jr, Raja Gabaglia C, Damasceno L, Wakimoto M, Ribeiro Nogueira RM, Carvalho de Sequeira P, Machado Siqueira A, Abreu de Carvalho LM, Cotrim da Cunha D, Calvet GA, Neves ES, Moreira $\mathrm{ME}$, Rodrigues Baião $\mathrm{AE}$, Nassar de Carvalho $\mathrm{PR}$, Janzen C, Valderramos SG, Cherry JD, Bispo de Filippis AM, Nielsen-Saines K: Zika virus infection in pregnant women in Rio de Janeiro - preliminary report. N Engl J Med 2016;doi: 10.1056/NEJMoa1602412.

54 Carteaux G, Maquart M, Bedet A, Contou D, Brugières P, Fourati S, Cleret de Langavant L, de Broucker T, Brun-Buisson C, Leparc-Goffart I, Mekontso Dessap A: Zika virus associated with meningoencephalitis. $\mathrm{N}$ Engl J Med 2016;374:1595-1596.

55 Kleber de Oliveira W, Cortez-Escalante J, de Oliveira WTGH, do Carmo GMI, Henriques CMP, Coelho GE, de França GVA: Increase in reported prevalence of microcephaly in infants born to women living in areas with confirmed Zika virus transmission during the first trimester of pregnancy - Brazil, 2015. MMWR Morb Mortal Wkly Rep 2016;65:242-247.

56 Jouannic JM, Friszer S, Leparc-Goffart I, Garel C, Eyrolle-Guignot D: Zika virus infection in French Polynesia. Lancet 2016;387:1051-1052.

57 Karwowski MP, Nelson JM, Staples JE, Fischer M Fleming-Dutra KE, Villanueva J, Powers AM, Mead P, Honein MA, Moore CA, Rasmussen SA: Zika virus disease: a CDC update for pediatric health care providers. Pediatrics 2016;137:e20160621.

58 Tang H, Hammack C, Ogden SC, Wen Z, Qian X, Li Y, Yao B, Shin J, Zhang F, Lee EM, Christian KM, Didier RA, Jin P, Song H, Ming GL: Zika virus infects human cortical neural progenitors and attenuates their growth. Cell Stem Cell 2016;18:587-590.

59 Garcez PP, Loiola EC, Madeiro da Costa RF, Higa L, Trindade P, Delvecchio R, Nascimento JM, Brindeiro RM, Tanuri A, Rehen SK: Zika virus impairs growth in human neurospheres and brain organoids. Science 2016;352:816-818.

60 Centers for Disease Control and Prevention: Zika Virus - Symptoms, Diagnosis, and Treatment. 2016, as of March 11. www.cdc.gov/zika/symptoms/index.html (last accessed September 27, 2016).

61 Hodge JG, Corbett A, Repka A, Judd PJ: Zika virus and global implications for reproductive health reforms. Disaster Med Public Health Prep 2016; doi: 10.1017/ dmp.2016.34.

62 Marrs C, Olson G, Saade G, Hankins G, Wen T, Patel J, Weaver S: Zika virus and pregnancy: a review of the literature and clinical considerations. Am J Perinatol 2016;33:625-639. 
63 Oduyebo T, Petersen EE, Rasmussen SA, Mead PS, Meaney-Delman D, Renquist CM, Ellington SR, Fischer M, Staples JE, Powers AM, Villanueva J, Galang RR, Dieke A, Muñoz JL, Honein MA, Jamieson DJ: Update: interim guidelines for health care providers caring for pregnant women and women of reproductive age with possible Zika virus exposure - United States, 2016. MMWR Morb Mortal Wkly Rep 2016;65: 122-127.

64 Auswärtiges Amt: Merkblatt für Beschäftigte und Reisende. Zika-Virus-Infektion. www.auswaertiges-amt.

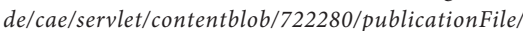
212139/Zika-Virus.pdf (last accessed September 27, 2016).

65 Althouse BM, Hanley KA, Diallo M, Sall AA, Ba Y, Faye O, Diallo D, Watts DM, Weaver SC, Cummings DA: Impact of climate and mosquito vector abundance on sylvatic arbovirus circulation dynamics in Senegal. Am J Trop Med Hyg 2015;92:88-97.

66 Musso D, Cao-Lormeau VM, Gubler DJ: Zika virus: following the path of dengue and chikungunya? Lancet 2015;386:243-244.

67 Musso D, Nhan T, Robin E, Roche C, Bierlaire D, Zisou K, Shan Yan A, Cao-Lormeau VM, Broult J: Potential for Zika virus transmission through blood transfusion demonstrated during an outbreak in French Polynesia, November 2013 to February 2014. Euro Surveill 2014;19:pii=20761.

68 Barchfield J, Henao LA: Brazil health official confirms Zika spread via transfusion. AP News February 4, 2016. http://bigstory.ap.org/article/92abd26a431647fdb 6b3ccb7459e4053/brazil-health-official-confirm-zikaspread-transfusion (last accessed September 27, 2016).

69 Cunha MS, Esposito DLA, Rocco IM, Maeda AY Vasami FGS, Nogueira JS, de Souza RP, Suzuki A, Addas-Carvalho M, Barjas-Castro MDL, Resende MR, Stucchi RSB, Boin Ide F, Katz G, Angerami RN, da Fonseca BAL: First complete genome sequence of Zika virus (Flaviviridae, Flavivirus) from an autochthonous transmission in Brazil. Genome Announc 2016;4: e00032-16.

70 Besnard M, Lastère S, Teissier A, Cao-Lormeau VM, Musso D: Evidence of perinatal transmission of Zika virus, French Polynesia, December 2013 and February 2014. Euro Surveill 2014;19:pii=20751.

71 Hills SL, Russell K, Hennessey M, Williams C, Oster AM, Fischer M, Mead P: Transmission of Zika virus through sexual contact with travelers to areas of ongoing transmission - continental United States, 2016. MMWR Morb Mortal Wkly Rep 2016;65:215-216.

72 Venturi G, Zammarchi L, Fortuna C, Remoli M, Benedetti E, Fiorentini C, Trotta M, Rizzo C, Mantella A, Rezza G, Bartoloni A: An autochthonous case of Zika due to possible sexual transmission, Florence, Italy, 2014. Euro Surveill 2016;21:pii $=30148$.

73 Musso D, Roche C, Nhan TX, Robin E, Teissier A, Cao-Lormeau VM: Detection of Zika virus in saliva. Clin Virol 2015;68:53-55.

74 Mansuy JM, Dutertre M, Mengelle C, Fourcade C, Marchou B, Delobel P, Izopet J, Martin-Blondel G: Zika virus: high infectious viral load in semen, a new sexually transmitted pathogen? Lancet Infect Dis 2016; $16: 405$.

75 Atkinson B, Hearn P, Afrough B, Lumley S, Carter D, Aarons EJ, Simpson AJ, Brooks TJ, Hewson R: Detection of Zika virus in semen. Emerg Infect Dis 2016;22: 940.

76 Rowland A, Washington CI, Sheffield JS, Pardo-Villamizar CA, Segars JH: Zika virus infection in semen: a call to action and research. J Assist Reprod Genet 2016; 33:435-437.
77 Mizuno Y, Kotaki A, Harada F, Tajima S, Kurane I, Takasaki T: Confirmation of dengue virus infection by detection of dengue virus type 1 genome in urine and saliva but not in plasma. Trans R Soc Trop Med Hyg 2007;101:738-739.

78 Poloni TR, Oliveira AS, Alfonso HL, Galvão LR, Amarilla AA, Poloni DF, Figueiredo LT, Aquino VH: Detection of dengue virus in saliva and urine by real time RT-PCR. Virol J 2010;7:22.

79 Hirayama T, Mizuno Y, Takeshita N, Kotaki A, Tajima S, Omatsu T, Sano K, Kurane I, Takasaki T: Detection of dengue virus genome in urine by real-time reverse transcriptase PCR: a laboratory diagnostic method useful after disappearance of the genome in serum. J Clin Microbiol 2012;50:2047-2052.

80 Musso D, Roche C, Robin E, Nhan T, Teissier A, CaoLormeau VM: Potential sexual transmission of Zika virus. Emerg Infect Dis 2015;21:359-361. Erratum in Emerg Infect Dis 2015;21:552.

81 Gourinat AC, O'Connor O, Calvez E, Goarant C, Dupont-Rouzeyrol M: Detection of Zika virus in urine. Emerg Infect Dis 2015;21:84-86.

82 de M Campos R, Cirne-Santos C, Meira GL, Santos LL, de Meneses MD, Friedrich J, Jansen S, Ribeiro MS, da Cruz IC, Schmidt-Chanasit J, Ferreira DF: Prolonged detection of Zika virus RNA in urine samples during the ongoing Zika virus epidemic in Brazil. J Clin Virol 2016;77:69-70.

83 Barzon L, Pacenti M, Berto A, Sinigaglia A, Franchin E, Lavezzo E, Brugnaro P, Palù G: Isolation of infectious Zika virus from saliva and prolonged viral RNA shedding in a traveller returning from the Dominican Republic to Italy, January 2016. Euro Surveill 2016; 21:pii=30159.

84 Rezza G: Dengue and chikungunya: long-distance spread and outbreaks in naïve areas. Pathog Glob Health 2014;108:349-355.

85 Roth A, Mercier A, Lepers C, Hoy D, Duituturaga S, Benyon E, Guillaumot L, Souarès Y: Concurrent outbreaks of dengue, chikungunya and Zika virus infections - an unprecedented epidemic wave of mosquitoborne viruses in the Pacific 2012-2014. Euro Surveill 2014;19:pii=20929.

86 Rodhain F, Gonzalez JP, Mercier E, Helynck B, Larouze $\mathrm{B}$, Hannoun $\mathrm{C}$ : Arbovirus infections and viral haemorrhagic fevers in Uganda: a serological survey in Karamoja district, 1984. Trans R Soc Trop Med Hyg 1989;83:851-854

87 Henderson BE, Kirya GB, Hewitt LE: Serological survey for arboviruses in Uganda, 1967-69. Bull World Health Organ 1970;42:797-805.

88 Darwish MA, Hoogstraal H, Roberts TJ, Ahmed IP, Omar F: A sero-epidemiological survey for certain arboviruses (Togaviridae) in Pakistan. Trans R Soc Trop Med Hyg 1983;77:442-445.

89 Hammon WM, Schrack WD Jr, Sather GE: Serological survey for arthropod-borne virus infections in the Philippines. Am J Trop Med Hyg 1958;7:323-328.

90 Diagne CT, Diallo D, Faye O, Ba Y, Faye O, Gaye A, Dia I, Faye O, Weaver SC, Sall AA, Diallo M: Potential of selected Senegalese Aedes spp. mosquitoes (Diptera: Culicidae) to transmit Zika virus. BMC Infect Dis 2015; 15:492.

91 Wolfe ND, Kilbourn AM, Karesh WB, Rahman HA, Bosi EJ, Cropp BC, Andau M, Spielman A, Gubler DJ: Sylvatic transmission of arboviruses among Bornean orangutans. Am J Trop Med Hyg 2001;64:310-316.

92 Boorman JP, Porterfield JS: A simple technique for infection of mosquitoes with viruses; transmission of Zika virus. Trans R Soc Trop Med Hyg 1956;50:238242.
93 Wong PS, Li MZ, Chong CS, Ng LC, Tan CH: Aedes (Stegomyia) albopictus (Skuse): a potential vector of Zika virus in Singapore. PLoS Negl Trop Dis 2013; 7:e2348.

94 Lanciotti RS, Kosoy OL, Laven JJ, Velez JO, Lambert AJ, Johnson AJ, Stanfield SM, Duffy MR: Genetic and serologic properties of Zika virus associated with an epidemic, Yap State, Micronesia, 2007. Emerg Infect Dis 2008;14:1232-1239.

95 Baronti C, Piorkowski G, Charrel RN, Boubis L, Leparc-Goffart I, de Lamballerie X: Complete coding sequence of Zika virus from a French Polynesia outbreak in 2013. Genome Announc 2014;2:e00500-14.

96 Aubry M, Finke J, Teissier A, Roche C, Broult J, Paulous S, Desprès P, Cao-Lormeau VM, Musso D: Seroprevalence of arboviruses among blood donors in French Polynesia, 2011-2013. Int J Infect Dis 2015;41: 11-12.

97 Calvet GA, Filippis AM, Mendonça MC, Sequeira PC Siqueira AM, Veloso VG, Nogueira RM, Brasil P: First detection of autochthonous Zika virus transmission in a HIV-infected patient in Rio de Janeiro, Brazil. J Clin Virol 2016;74:1-3.

98 Teixeira MG, Costa MCN, Barreto F, Barreto ML: Dengue: twenty-five years since reemergence in Brazil. Cad Saude Publica 2009;25:S7-18

99 Honorio NA, Camara DC, Calvet GA, Brasil P: Chikungunya, an arbovirus infection in the process of establishment and expansion in Brazil. Cad Saude Publica 2015;31:906-908.

100 WHO: The history of Zika virus. www.who.int/emer gencies/zika-virus/timeline/en/ (last accessed September 27, 2016).

101 European Centre for Disease Prevention and Control: Countries and territories with local Zika transmission. http://ecdc.europa.eu/en/healthtopics/zika_virus_infection/zika-outbreak/Pages/Zika-countries-with-transmission.aspx (last accessed September 27, 2016).

102 Tappe D, Rissland J, Gabriel M, Emmerich P, Günther S, Held G, Smola S, Schmidt-Chanasit J: First case of laboratory-confirmed Zika virus infection imported into Europe, November 2013. Euro Surveill 2014;19: $\mathrm{pii}=20685$.

103 Maria A, Maquart M, Makinson A, Flusin O, Segondy M, Leparc-Goffart I, Le Moing V, Foulongne V: Zika virus infections in three travellers returning from South America and the Caribbean respectively, to Montpellier, France, December 2015 to January 2016. Euro Surveill 2016;21:pii=30131.

104 Korhonen E, Huhtamo E, Smura T, Kallio-Kokko H, Raassina M, Vapalahti O: Zika virus infection in a traveller returning from the Maldives, June 2015. Euro Surveill 2016;21:pii=30107.

105 Ginier M, Neumayr A, Günther S, Schmidt-Chanasit J Blum J: Zika without symptoms in returning travellers: What are the implications? Travel Med Infect Dis 2016;14:16-20.

106 Gyurech D, Schilling J, Schmidt-Chanasit J, Cassinotti P, Kaeppeli F, Dobec M: False positive dengue NS1 antigen test in a traveller with an acute Zika virus infection imported into Switzerland. Swiss Med Wkly 2016; 146:w14296.

107 Monlun E, Zeller H, Le Guenno B, Traoré-Lamizana M, Hervy JP, Adam F, Ferrara L, Fontenille D, Sylla R, Mondo M: Surveillance of the circulation of arbovirus of medical interest in the region of eastern Senegal (in French). Bull Soc Pathol Exot 1993;86:21-28.

108 Diallo D, Sall AA, Diagne CT, Faye O, Faye O, Ba Y, Hanley KA, Buenemann M, Weaver SC, Diallo M: Zika virus emergence in mosquitoes in southeastern Senegal, 2011. PLoS One 2014;9:e109442. 
109 Blümel J, Burger R, Gerlich W, Gürtler L, Heiden M, Hitzler W, Jansen B, Klamm H, Lefèvre H, Löwer J, Ludwig WD, Montag-Lessing T, Offergeld R, Paessens A, Pauli G, Seitz R, Schlenkrich U, Willkommen H: Arboviruses - viruses transmissible by arthropods. Transfus Med Hemother 2005;32:209-217.

110 Grunnill M, Boots M: How important is vertical transmission of dengue viruses by mosquitoes (Diptera: $\mathrm{Cu}$ licidae)? J Med Entomol 2016;53:1-19.

111 Musso D, Nilles EJ, Cao-Lormeau VM: Rapid spread of emerging Zika virus in the Pacific area. Clin Microbiol Infect 2014;20:O595-596.

112 Ledermann JP, Guillaumot L, Yug L, Saweyog SC, Tided M, Machieng P, Pretrick M, Marfel M, Griggs A, Bel M, Duffy MR, Hancock WT, Ho-Chen T, Powers AM: Aedes hensilli as a potential vector of Chikungunya and Zika viruses. PLoS Negl Trop Dis 2014;8: e3188.

113 Kek R, Hapuarachchi HC, Chung CY, Humaidi MB, Razak MA, Chiang S, Lee C, Tan CH, Yap G, Chong CS, Lee KS, Ng LC: Feeding host range of Aedes albopictus (Diptera: Culicidae) demonstrates its opportunistic host-seeking behavior in rural Singapore. J Med Entomol 2014;51:880-884.

114 Erguler K, Smith-Unna SE, Waldock J, Proestos Y, Christophides GK, Lelieveld J, Parham PE: Large-scale modelling of the environmentally-driven population dynamics of temperate Aedes albopictus (Skuse). PLoS One 2016;11:e0149282.

115 Becker N, Krüger A, Kuhn C, Plenge-Bönig A, Thomas SM, Schmidt-Chanasit J, Tannich E: Mosquitoes as vectors for exotic pathogens in Germany (in German). Bundesgesundheitsbl Gesundheitsforsch Gesundheitsschutz. 2014;57:531-540.

116 European Centre for Disease Prevention and Control: Aedes albopictus. http://ecdc.europa.eu/en/healthtopics/ vectors/mosquitoes/Pages/aedes-albopictus.aspx (last accessed September 27, 2016).

117 Kampen H, Medlock JM, Vaux AG, Koenraadt CJ, van Vliet AJ, Bartumeus F, Oltra A, Sousa CA, Chouin S, Werner D: Approaches to passive mosquito surveillance in the EU. Parasit Vectors 2015;8:9.

118 Schaffner F, Medlock JM, Van Bortel W: Public health significance of invasive mosquitoes in Europe. Clin Microbiol Infect 2013;19:685-692.

119 Tomasello D, Schlagenhauf P: Chikungunya and dengue autochthonous cases in Europe, 2007-2012. Travel Med Infect Dis 2013;11:274-284.

120 Vega-Rúa A, Lourenço-de-Oliveira R, Mousson L, Vazeille M, Fuchs S, Yébakima A, Gustave J, Girod R, Dusfour I, Leparc-Goffart I, Vanlandingham DL, Huang YJ, Lounibos LP, Mohamed Ali S, Nougairede A, de Lamballerie X, Failloux AB: Chikungunya Virus Transmission potential by Local Aedes mosquitoes in the Americas and Europe. PLoS Negl Trop Dis 2015; 9:e0003780.

121 Becker N, Geier M, Balczun C, Bradersen U, Huber K, Kiel E, Krüger A, Lühken R, Orendt C, Plenge-Bönig A, Rose A, Schaub GA, Tannich E: Repeated introduction of Aedes albopictus into Germany, July to October 2012. Parasitol Res 2013;112:1787-1790.

122 Werner D, Kampen H: Aedes albopictus breeding in southern Germany, 2014. Parasitol Res 2015;114:831834.

123 McCrae AW, Kirya BG: Yellow fever and Zika virus epizootics and enzootics in Uganda. Trans R Soc Trop Med Hyg 1982;76:552-562.
124 Monath TP, Craven RB, Muth DJ, Trautt CJ, Calisher $\mathrm{CH}$, Fitzgerald SA: Limitations of the complementfixation test for distinguishing naturally acquired from vaccine-induced yellow fever infection in flavivirushyperendemic areas. Am J Trop Med Hyg 1980;29: 624-634.

125 Centers for Disease Control and Prevention: Memorandum - Revised Diagnostic Testing for Zika, Chikungunya, and Dengue Viruses in US Public Health Laboratories. www.cdc.gov/zika/pdfs/denvchikvzikvtesting-algorithm.pdf (last accessed September 27, 2016)

126 Centers for Disease Control and Prevention: New CDC Laboratory Test for Zika Virus Authorized for Emergency Use by FDA - Media Statement. www.cdc. gov/media/releases/2016/s0226-laboratory-test-forzika-virus.html (last accessed September 27, 2016).

127 Choumet V, Desprès P: Dengue and other flavivirus infections. Rev Sci Tech 2015;34:473-478,467-472.

128 Zammarchi L, Stella G, Mantella A, Bartolozzi D, Tappe D, Günther S, Oestereich L, Cadar D, MuñozFontela C, Bartoloni A, Schmidt-Chanasit J: Zika virus infections imported to Italy: clinical, immunological and virological findings, and public health implications. J Clin Virol 2015;63:32e35.

129 Chung SJ, Krishnan PU, Leo YS: Two cases of falsepositive dengue non-structural protein 1 (NS1) antigen in patients with hematological malignancies and a review of the literature on the use of NS1 for the detection of dengue infection. Am J Trop Med Hyg 2015;92: 367-369.

130 Atkinson B, Hearn P, Afrough B, Lumley S, Carter D, Aarons EJ, Simpson AJ, Brooks TJ, Hewson R: Detection of Zika virus in semen. Emerg Infect Dis 2016;22: 940.

131 Faye O, Dupressoir A, Weidmann M, Ndiaye M, Alpha Sall A: One-step RT-PCR for detection of Zika virus. J Clin Virol 2008;43:96-101.

132 Calvet G, Aguiar RS, Melo AS, Sampaio SA, de Filippis I, Fabri A, Araujo ES, de Sequeira PC, de Mendonça MC, de Oliveira L, Tschoeke DA, Schrago CG, Thompson FL, Brasil P, Dos Santos FB, Nogueira RM, Tanuri A, de Filippis AM: Detection and sequencing of Zika virus from amniotic fluid of fetuses with microcephaly in Brazil: a case study. Lancet Infect Dis 2016; 16:653-660.

133 Tappe D, Nachtigall S, Kapaun A, Schnitzler P, Günther S, Schmidt-Chanasit J: Acute Zika virus infection after travel to Malaysian Borneo, September 2014. Emerg Infect Dis 2015;21:911-913.

134 Robert Koch-Institut: Häufung von Mikrozephalie in Südamerika stellt gesundheitliche Notlage von internationaler Tragweite dar. Epid Bull 2016;5:40-41.

135 Bundesaerztekammer: Hemotherapy guidelines. www. bundesaerztekammer.de/fileadmin/user_upload/downloads/RiliHaemotherapie2010.pdf, and www.bundesaerztekammer.de/aerzte/medizin-ethik/wissenschaftlicher-beirat/veroeffentlichungen/haemotherapie-transfusionsmedizin/richtlinie/ (last accessed September 27, 2016).

136 Food and Drug Administration: Recommendations for Donor Screening, Deferral, and Product Management to Reduce the Risk of Transfusion-Transmission of Zika Virus. Guidance for Industry. www.fda.gov/downloads/BiologicsBloodVaccines/GuidanceComplianceRegulatoryInformation/Guidances/Blood/ UCM486360.pdf (last accessed September 27, 2016).
137 Staples JE, Dziuban EJ, Fischer M, Cragan JD, Rasmussen SA, Cannon MJ, Frey MT, Renquist CM, Lanciotti RS, Muñoz JL, Powers AM, Honein MA, Moore CA: Interim guidelines for the evaluation and testing of infants with possible congenital Zika virus infection United States, 2016. MMWR Morb Mortal Wkly Rep 2016;65:63-67.

138 Broutet N, Krauer F, Riesen M, Khalakdina A, Almiron M, Aldighieri S, Espinal M, Low N, Dye C: Zika virus as a cause of neurologic disorders. N Engl J Med 2016;374:1506-1509.

139 Malone RW, Homan J, Callahan MV, GlasspoolMalone J, Damodaran L, Schneider Ade B, Zimler R, Talton J, Cobb RR, Ruzic I, Smith-Gagen J, Janies D, Wilson J; Zika Response Working Group: Zika virus: medical countermeasure development challenges. PLoS Negl Trop Dis 2016; 10:e0004530.

140 Regis L, da Silva SB, Melo-Santos MA: The use of bacterial larvicides in mosquito and black fly control programmes in Brazil. Mem Inst Oswaldo Cruz 2000;95: 207-210.

141 Basarab M, Bowman C, Aarons EJ, Cropley I: Zika virus. BMJ 2016;352:i1049.

142 Dupont-Rouzeyrol M, Biron A, O’Connor O, Huguon E, Descloux E: Infectious Zika viral particles in breastmilk. Lancet 2016;387:1051.

143 Herriman R: Transfusion-associated Zika virus reported in Brazil, Latin America and the Caribbean; Outbreak News Today December 18, 2015. http://outbreaknewstoday.com/transfusion-associated-zika-virusreported-in-brazil-76935/ (last accessed September 27, 2016).

144 Kreil TR: West Nile virus: recent experience with the model virus approach. Dev Biol (Basel) 2004;118:101105.

145 Jakubik JJ, Vicik SM, Tannatt MM, Kelley BD: West Nile virus inactivation by the solvent/detergent steps of the second and third generation manufacturing processes for B-domain deleted recombinant factor VIII. Haemophilia 2004;10:69-74.

146 Leydold SM, Farcet MR, Kindermann J, Modrof J, Pölsler G, Berting A, Howard MK, Barrett PN, Kreil TR: Chikungunya virus and the safety of plasma products. Transfusion 2012;52:2122-2130.

147 Burnouf T, Chou ML, Cheng LH, Li ZR, Wu YW, ElEkiaby M, Tsai KH: Dengue virus inactivation by minipool TnBP/Triton X-45 treatment of plasma and cryoprecipitate. Vox Sang 2013;104:1-6.

148 Hellstern P, Solheim BG: The use of solvent/detergent treatment in pathogen reduction of plasma. Transfus Med Hemother 2011;38:65-70

149 Kaiser-Guignard J, Canellini G, Lion N, Abonnenc M, Osselaer JC, Tissot JD: The clinical and biological impact of new pathogen inactivation technologies on platelet concentrates. Blood Rev 2014;28:235-241.

150 Rock G: A comparison of methods of pathogen inactivation of FFP. Vox Sang 2011;100:169-178.

151 Aubry M, Richard V, Green J, Broult J, Musso D: Inactivation of Zika virus in plasma with amotosalen and ultraviolet A illumination. Transfusion 2016;56:33-40.

152 Bundesrat: Verordnung des Bundesministeriums für Gesundheit: Verordnung zur Anpassung der Meldepflichten nach dem Infektionsschutzgesetz an die epidemische Lage (IfSG-Meldepflicht-Anpassungsverordnung - IfSGMeldAnpV) Drucksache 75/16 vom 04.02.2016 www.bundesrat.de/drs.html?id=75-16 (last accessed September 27, 2016). 